\title{
DAMPAK PERUBAHAN PADA PEMBELAJARAN SEJARAH DI MASA WABAH PANDEMI VIRUS COVID-19
}

\author{
Alfianoor Septiawan \\ Program Studi Pendidikan Sejarah \\ Fakultas Keguruan dan IImu Pendidikan \\ Universitas Lambung Mangkurat \\ Banjarmasin \\ alfianoorseptiawan@gmail.com
}

\begin{abstract}
ABSTRAK
Penelitian ini membahas tentang perubahan pembelajaran sejarah dari pembelajaran luring ke pembelajaran daring pada masa wabah pandemi virus Covid-19. Menyebarnya virus Covid-19 membuat banyak perubahan dalam berbagai aspek bidang salah satunya pada bidang pendidikan. Perubahan dalam pendidikan ini pada awalnya membuat adaptasi baru terhadap bentuk pembelajaran yang akan diterapkan pada peserta didik. Perubahan bentuk pembelajaran ini merupakan sebuah imbas dari menyebarnya virus Covid-19 yang menyebar dihampir seluruh wilayah di dunia, tidak terkecuali Indonesia. Pembelajaran di Indonesia yang dominan dilaksanakan secara tatap muka atau familiar dikenal sebagai pembelajaran luring beralih menjadi pembelajaran melalui jaringan atau yang saat ini dikenal dengan pembelajaran daring. Pembelajaran sejarah tentunya juga harus beradaptasi dalam bentuk pembelajaran secara daring sehingga tujuan pembelajaran dapat terpenuhi sehingga kualitas pembelajaran dapat berjalan dan tentunya meningkat.
\end{abstract}

Kata Kunci:, Perubahan, Pembelajaran Daring, dan Sejarah.

\section{PENDAHULUAN}

Pendidikan merupakan salah satu wadah yang digunakan sebagai bentuk meningkatkan kualitas masyarakat dalam sebuah negara. Tanpa pendidikan masyarakat tidak akan dapat berkembang secara kualitas dan daya pikir, sehingga akan ketika masyarakat jauh dari pendidikan maka terjadi dalam masyarakat adalah kekacauan seperti tingkat kriminalitas akan meningkat, kesenjangan sosial semakin besar, hingga yang berbahaya adalah masyarakat kehilangan identitas kebangsaan karena tidak mengenali dirinya sebagai bagian dari warga negara. Bahkan tujuan dari pendidikan sendiri adalah sebagai sebuah pembentukan sebuah generasi tidak hanya menguasai suatu keilmuan yang bersifat keduniaan seperti ilmu pengetahuan, tetapi juga memiliki 
karakter yang baik dari segi moral ataupun etika (Wahidah, M. N., Putro, H. P., Syaharuddin, S., Prawitasari, M., Anis, M. Z. A., \& Susanto, H. (2021:10).

Ditengah pendidikan yang semakin meningkat dengan seringnya terjadi perubahan-perubahan dalam evaluasi pendidikan dari pemerintah pusat melalui kementerian pendidikan, faktanya dimasa sekarang dunia pendidikan dihadapkan pada sebuah wabah pandemi virus Covid-19 yang membuat sektor pendidikan harus terkena imbasnya, dengan marajalelanya penyebaran virus Covid-19 ini membuat pemerintah pusat melalui kementerian pendidikan menghimbau sekolah-sekolah dan instansi pendidikan untuk membuat kebijakan dalam pembelajaran yakni perubahan dari sistem pembelajaran tatap muka atau luring beralih menjadi pembelajaran melalui jaringan atau yang saat ini kerap dikenal dengan pembelajaran daring.

Perubahan pembelajaran dari luring menjadi pembelajaran daring ini juga pada akhirnya diterapkan pada seluruh mata pelajaran pada tiap sekolah, salah satunya pada pembelajaran sejarah. Menurut Anis, M. Z. A. (2015: 54) mendefiniskan bahwa sejarah merupakan suatu keilmuan mengenai suatu aktivitas masyarakat dalam periode waktu. Pembelajaran sejarah yang kerap dilaksanakan secara luring harus dilaksanakan secara daring sehingga pendidik harus mengubah metode pendekatan pembelajarannya untuk menyesuaikan dengan adaptasi pembelajaran yang sebenarnya terkesan baru dilaksanakan walaupun bentuk pembelajaran daring sudah ada sebelumnya. Dengan pembelajaran daring ini setiap pelaku pendidikan dapat bekerja sama baik dari segi pendidik, peserta didik, ataupun instansi pendidikan dapat meningkatkan kualitas diri yakni pendidik dapat menguasai kemajuan teknologi pembelajaran yang dapat digunakan dalam pembelajaran daring, peserta didik dapat dengan cermat dalam ikut melaksanakan pembelajaran daring dalam hal ini dapat mengikuti pembelajaran dengan baik yakni dengan aktif dalam pembelajaran dan menghargai pendidik dengan menjaga etika dan moral dalam pembelajaran, dan instansi pendidikan dapat membuat kebijakan pendukung pembelajaran daring dengan kebijakan yang sebijak-bijaknya sebuah gagasan yang dapat mendukung pembelajaran daring. 


\section{PEMBAHASAN}

\section{Penerapan Pembelajaran Daring di Sekolah}

Pembelajaran daring adalah suatu inovasi dalam pendidikan yang melibatkan unsur teknologi informasi dalam pembelajaran (Fitriyani, Y., Fauzi, I., \& Sari, M. Z. (2020:166). Pembelajaran daring merupakan bentuk pembelajaran yang secara umum terhitung baru diterapkan pada pelaksanaan pembelajaran di Sekolah Menengah Atas (SMA), hal ini pun juga tidak terlepas dari penyebaran virus Covid-19 yang membuat munculnya kebijakan untuk membatasi mobilitas diluar rumah tidak terkecuali kegiatan belajar mengajar di Sekolah. Sehingga munculnya sebuah kebijakan agar pembelajaran dapat tetap berjalan maka pembelajaran daring merupakan solusi yang dapat digunakan pendidik dalam hal ini guru untuk dapat melaksanakan pembelajaran dengan baik. Hal ini pada akhirnya membuat pendidik untuk menyesuaikan kembali Rencana Pelaksanaan Pembelajaran (RPP) yang sudah dirancang pendidik dalam pembelajaran. Dalam pembuatan Rencana Pelaksanaan Pembelajaran (RPP) seorang pendidik biasanya berpatokan pada Silabus yang telah disediakan oleh pihak Sekolah (Efendi, I., Prawitasari, M., \& Susanto, H. (2021:24). Dengan demikian penerapan pembelajaran daring harus disesuaikan dengan Rencana Pelaksanaan Pembelajaran (RPP) sehingga pelaksanaan pembelajaran daring dapat berjalan tepat, efektif, dan efisien.

Pendidik dalam penerapan pembelajaran daring kebanyakan menggunakan platform video conference seperti Zoom, Google Meet, dan sejenisnya sehingga memungkinkan interaksi secara langsung dengan peserta didik dalam proses berjalannya pembelajaran. Walaupun demikian bukan berarti pembelajaran tanpa adanya kendala, terkadang permasalahan yang muncul cukup signifikan dalam pembelajaran daring adalah permasalahan jaringan internet sehingga pembelajaran daring sendiri tidak optimal diterapkan dan kebanyakan yang dominan mengalami permasalahan dalam pembelajaran daring adalah pendidik ataupun peserta didik yang berdomisili didaerah yang berada diluar perkotaan atau diwilayah pedesaan. 


\section{Penerapan Pembelajaran Daring Pada Pembelajaran Sejarah}

Dalam pembelajaran sejarah tidak bisa dilepaskan pada cara berpikir sejarah dimana dalam berpikir sejarah menekankan pada sikap kritis terhadap sebuah fakta, mensistesiskan, menafsirkan, dan mengaitkan antara suatu peristiwa dimasa lampau dengan masa sekarang (Anis, M. Z. A., Putro, H. P. N., Susanto, H., \& Hastuti, K. P. 2020:7896). Sehingga pembelajaran sejarah merupakan pembelajaran yang membuat peserta didik dapat berpikir kritis terhadap suatu hal baik itu pada peristiwa ataupun kritis terhadap suatu pemikiran dan ideologi. Pada pembelajaran sejarah ditengah wabah pandemi virus Covid-19 pembelajaran sejarah beradaptasi dalam penerapannya sehingga pembelajaran sejarah dapat berjalan baik.

Dalam pembelajaran daring penggunaan media sangatlah vital karena dengan penggunaan media yang efektif dan efisien pembelajaran daring dapat dilaksanakan dengan baik. Menurut Susanto, H., Irmawati, I., Akmal, H., \& Abbas, E. W. (2021:66) dalam pembelajaran, penggunaan media dimaksudkan sebagai suatu alat bantu mengajar. Penggunaan media pada pembelajaran sejarah secara daring sangatlah penting karena pembelajaran sejarah yang menuntut untuk melatih daya pikir kritis terhadap sesuatu tentunya memerlukan media yang dapat mendukung pembelajaran sehingga tujuan dari pembelajaran dapat terpenuhi ditambah dengan bentuk pembelajaran daring yang secara penerapan tentu berbeda dengan pembelajaran tatap muka atau luring.

Pembelajaran sejarah secara daring dapat menggunakan media yang mendukung pembelajaran secara baik, salah satunya ada penggunaan media film dokumenter. Dalam penggunaan media film dokumenter memungkinkan peserta didik dapat melakukan pengamatan mengenai gambaran suatu fakta yang terjadi dimasa lampau sehingga peserta didik dapat berpikir secara kritis dengan sesuatu yang mereka amati (Susanto, H., Irmawati, I., Akmal, H., \& Abbas, E. W. (2021:67). Tentunya bentuk pembelajaran menggunakan media film dokumenter tidak hanya membuat peserta didik dapat mengasah cara berpikir kritis tetapi juga dapat memberikan menyamanan dalam mengikuti pembelajaran sejarah secara menyenangkan. 
Walaupun demikian terdapat begitu banyak media yang dapat mendukung pembelajaran sejarah secara daring salah satunya juga seperti penggunaan aplikasi permainan yang dapat membuat peserta didik dapat aktif dalam pembelajaran. Tetapi walaupun demikian diperlukan keaktifan dan pemahaman dari seluruh komponen pendidikan supaya pembelajaran daring pada pembelajaran sejarah dapat berjalan dengan baik, efektif, dan efisien sehingga tujuan pembelajaran dapat terpenuhi.

\section{SIMPULAN}

Pembelajaran daring pada pembelajaran sejarah tentunya merupakan sebuah tantangan dalam pendidikan, karena pembelajaran sejarah merupakan pembelajaran yang menuntut cara berpikir kritis peserta didik dalam proses berjalannya kegiatan pembelajaran. Tentunya terdapat beberapa kendala yang menjadi permasalahan dalam pembelajaran daring salah satunya yang cukup sering terjadi adalah permasalahan terhadap koneksi jaringan internet yang kebanyakan mengganggu proses pembelajaran berlangsung sehingga dapat membuat kegiatan pembelajaran berjalan tidak efektif dan efisien. Dalam pembelajaran sejarah penggunaan media begitu penting apalagi dengan bentuk pembelajaran secara daring karena penggunaan media dapat membuat pemahaman peserta didik terhadap materi yang diajarkan dapat diserap dan juga tujuan dari pembelajaran yang dilaksanakan dapat dengan mudah tersampaikan.

\section{SARAN}

Dalam tulisan ini tentunya memerlukan sebuah telaah yang lebih dalam lagi sehingga dapat dikatakan tepat tetapi tanpa adanya realisasi terhadap bentuk pembelajaran yang dilaksanakan maka baik pendidik ataupun peserta didik tidak akan mengetahui hasil dari pembelajaran daring pada pembelajaran sejarah. Tentunya tanpa peningkatan pemahaman pendidik mengenai jenis pembelajaran daring maka akan sulit untuk mengimplementasikan pada pembelajaran yang diterapkan pada proses kegiatan ajar mengajar. 


\section{REFERENSI}

Anis, M. Z. A. (2015). Sejarah Bukan Warisan Melainkan Pembelajaran.

Anis, M. Z. A., Putro, H. P. N., Susanto, H., \& Hastuti, K. P. (2020). Historical Thinking Model in Achieving Cognitive Dimension of Indonesian History Learning. PalArch's Journal of Archaeology of Egypt/Egyptology, 17(7), 7894-7906.

Efendi, I., Prawitasari, M., \& Susanto, H. (2021). Implementasi Penilaian Pembelajaran Pada Kurikulum 2013 Mata Pelajaran Sejarah. Prabayaksa: Journal of History Education, 1(1), 21-25.

Fitriyani, Y., Fauzi, I., \& Sari, M. Z. (2020). Motivasi belajar mahasiswa pada pembelajaran daring selama pandemik covid-19. Jurnal Kependidikan: Jurnal Hasil Penelitian dan Kajian Kepustakaan di Bidang Pendidikan, Pengajaran dan Pembelajaran, 6(2), 165-175.

Susanto, H., Irmawati, I., Akmal, H., \& Abbas, E. W. (2021). Media Film Dokumenter Masuknya Islam Ke Nusantara dan Pengaruhnya Terhadap Keterampilan Berpikir Kritis Siswa. HISTORIA: Jurnal Program Studi Pendidikan Sejarah, 9(1).

Wahidah, M. N., Putro, H. P., Syaharuddin, S., Prawitasari, M., Anis, M. Z. A., \& Susanto, H. (2021). DINAMIKA PENDIDIKAN DASAR ISLAM SABILAL MUHTADIN BANJARMASIN (1986-2019). PAKIS (Publikasi Berkala Pendidikan Ilmu Sosial), 1(1). 